\title{
Environmental factors associated with fluctuation in the population density of the sugar-cane scales, Pulvinaria tenuvalvata (newstead) (hemipteran: coccidae)
}

\author{
M. S. Shalaby ${ }^{1, *}$, N. A. Abd El-Razek ${ }^{1}$ and A. A. Taman ${ }^{1}$ \\ ${ }_{1}^{1}$ Plant Protection Research Institute, Agriculture Research Center, Dokki •Giza, Egypt \\ *Correspondence: mshalaby@yahoo.com (M. Shalaby)
}

\section{ABSTRACT}

This study aims to monitor the effect of temperature and relative humidity on the population fluctuation of $P$. tenuivalvata. Ecological studies on population dynamic of $P$. tenuvalvata (Newstead) (hemipteran: coccidae) on sugarcane fields were studied in Aswan Governorate two successive seasons 2015-2016. Data showed that this pest was active during summer, autumn and winter from May to January). The insect had 3 generations per year. The first generation was observed during May, June and early of July. The second took place during July, August and $2^{\text {nd }}$ half of September. This generation can be regarded as the most economically important generation. The third generation lasted 3 months i.e. extended from November to the $2^{\text {nd }}$ week of January. The relationship between insect populations expressed as interval numbers of insects and prevailing weather factors in the two tested years revealed that significant and strong relation between interval of insects and corresponding of maximum and minimum temperature. The correlation coefficient values of the three considered weather factors are $(-0.6281,-0.5931$ and +0.8612$)$ in 2015 and $(+0.6109,+0.5428$ and +0.612$) 2016$ respectively. The effect of one degree of these factors (Unit effect) as indicted by the regression coefficient was about $(+.2 .95,+3.22$ and +3.92$)$ and $(-3.68,+2.11$ and +3.31$)$ from three factors during 2015 compared to insects in 2016, respectively. The explained variances E.V were calculated (as about 64.35 and 71.2 in 2015 and 2016, respectively. In conclusion, the effect of partial regression as indicated by unit effect was negative for maximum temperature.

Keywords: Aswan Governorate; Newstead; Hemiptera coccida

\section{NTRODUCTION}

Sugarcane is the major source of sugar production in Egypt. Sugar demands increase year after year due to the increase of habitant population. The yield of sugarcane is markedly influenced by numerous factors among which are agricultural practices among which are agricultural practices, fertilization and infestation by different pests.

One of the most interesting factors affecting sugar production (quantity and quality) are insect pests and fungal disease. Sugarcane is damaged by 35 insect species of hard and soft scale insect (Marreg et al., 1992)

The soft scale, Pulvinaria tenuvalvata (Newstead) was first recorded in sugarcane plantation at Attfieh (Giza Governorate) throughout the season 1995 (Ali et al., 1997); the infestation rate was $36.8 \%$ in $1995 / 96$ season. This rate progressively increased to reach, the maximum $71.4 \%$ in the next season (1996-1997). Further examination of sugarcane fields in Upper Egypt revealed the wide distribution of the pest in Giza, El-Minia, Sohag, Quena, Luxor, and Aswan were sugarcane in intensity cultivated. The most interest fact in the drastic increase of insect infestation in Quena, Luxor and Aswan where infestation rate multiplied 2,6 and 4.0 times, respectively (Shalaby 2002). These results reflect the severity, dangerous and bad situation of this pest on sugarcane in Upper Egypt.
Sugarcane produced about $73 \%$ of the total amount of sugar production (Anonymous 2004). It is only crop cultivated in Egypt for sugar production however, new plants in currently under construction for sugar beet at the northern part of the Nile Delta. Molasses, alcohol, vinegar and some other materials are by-products of the sugar industry. Sugarcane in Egypt is subjected to infestation with a good number of insect pests of which the sugarcane borers are the most important.

In general, sugarcane cultivated in large continuous areas and remain in the field for the whole year. This fore, a wide range of insect species cause the most significant losses. Some of these insects are major pests of regular occurrence and cover serious damage, others are minor species. Among of these insect pests are soft scale insects (Maarg et al., 1992).

During the last few years, it has been recorded the soft scale insect $P$. tenuivalvata (Newstead) as noticed firstly at Giza Governorate in 1995/1996 season and supported widely and quickly to cover 18 thousand Feddan in all sugarcane plantation in 2000/2001 season (Besheit et al., 2002). Sucking leaf juice can cause damage due to the loss of vigor; spots on the foliage due to toxin in the scale saliva (Valand et al., 1989).

The present study was designed to monitor the effect of temperature and relative humidity on the population fluctuation of $P$. tenuivalvata. 


\section{MATERIAL AND METHODS}

\section{Insect incidence in sugarcane fields}

The percentage of Infestation $=$ No. of infested leaves / Total no. of sampled leaves x100.

The population density of $P$. tenuivalvata was estimated in sugarcane fields at Awadlah District, Aswan Governorate throughout two successive seasons 2015 and 2016 to carry out this estimate, a sugarcane field of about one Feddan was chosen at Awadlah. Sugarcane plants received regular agricultural practices and no chemical treatments were applied. Sampling of 300 leaves were collected at random from four plots, $42 \mathrm{~m}^{2}$ each representing the cane field communed from $15^{\text {th }}$ of May to $15^{\text {th }}$ of January. In laboratory, upper and lower surfaces of each leaf were examined.

\section{The effect of weather factor}

The number of insect is influenced, in general, by many factors including population density, behavior of insects and weather factors. The seasonal fluctuation in the population density of P.T. in relation to three main weather factors namely the day maximum temperature ${ }^{\circ} \mathrm{C}(\mathrm{X} 1)$, the night minimum temperature ${ }^{\circ} \mathrm{C}\left(\mathrm{X}_{2}\right)$ and the daily mean relative humidity $\%\left(X_{3}\right)$ were obtained from the Agro-Meteorological station at Aswan Governorate between the change of number of insects and reading of three considered factors were calculated.

The simple correlation coefficient ( $r$ ) and regression coefficient (b), formula was adopted to find out the simultaneous effect of these factors, together, on the seasonal changes of insect.

End of the above mentioned factors on the one hand $(X)$ and the interval numbers of insects on the other (y). Partial regression method used in this analysis (termed the C-multiplies, (Fisher1950) was helpful in obtaining basic information about the amount of variability in the activity of insect, which could be attributed to these three factors, together, which was calculated as percentages of variance explained, (E V.\%).

\section{RESULTS AND DISCUSSION}

Data tabulated in Tables $(1,2)$ showed that the infestation numbers during the two successive seasons (2015\&2016).

The mean infestation varied in the two successive seasons with a markedly high population level in the 2015. In that year the numbers increased steadily from the first half of May onward to reach a total of 73 during May $112,209,322$, to reach of maximum 445 during September (Table 1). After September the numbers decreased gradually during October, November and December, respectively. Data in Table (2) indicate that the population in the infestation in 2016 showed the same trend though on a much smaller scale.

These results may be that. $P$. tenuivalvata pass winter as over wintering. Monthly fluctuation and population density of $P$. tenuivalvata in sugarcane fields demonstrated the occurrence of the highest density of adults throughout September-October (Table 1, 2). In two successive seasons.

These numbers were especially decreased to reach the minimum during November. Temperature and relative humidity through September and October ranged $23-25^{\circ} \mathrm{C}$ and $61-$ $65 \% \mathrm{RH}$. These results infer that weather of mild temperature and high humidity was the most favorable conditions for $P$. tenuivalvata development and build-up of its population. So, it could be concluded that these were three generations for $P$. tenuivalvata per year. The first occurred in April -May, the second in September, while the third one appeared during November, (Shalaby 2002).

Sugarcane crop is damaged by about 35 species of hard and soft scale insects belonging to the families Acleridae, Asterolecaniidae, Coccidae and Diaspididae in different caulis (Rao and Sankaran, 1969). In Egypt, Maareg et al. (1992) recorded Pulvinaria elongate on the leaves of sugarcane in Alexandria, while Pulvinaria tenuvalvato the first record on sugarcane foliage in plantation in upper Egypt (Ali et al.,1997). The complete and integration of the climatic in cadence effect is calculated as percentages of explained variance (E.V.\%) The partial regression values gives the average rate of population changes due to a unit change in any of the three factors under test.

Table (3) showed that simple correlation Coefficient between number of insects and prevailing weather factors were significantly negative for maximum, minimum temperature in (2015 and 2016) seasons and positive significant for relative humidity percentages. The effect of Partial regression as indicated by unit effect was negative for maximum temperature positive effect for minimum temperature and relative humidity. The unit effect of every factors was ($2.95,3.22$ and 3.92) \& (-3.68, 2.11 and 3.21) in 2015 and 2016 respectively Explained variance for two seasons were $(64.35 \%$ and $71.2 \%)$, respectively.

\section{CONCLUSION}

It could be concluded that the effect of partial regression as indicated by unit effect was negative for maximum temperature and had a 
positive effect for minimum temperature, and relative humidity on Pulvinaria tenuvalvata at Aswan Governorate.

\section{REFERENCES}

Ali, M.A., El-Khouly, A.S., El-Metwally, F.E.M., Shalaby, M.I.S., 1997. First recorded of the sugarcane scale, Saccharolecanium krugeri (Zehntner) in Giza, Egypt. Bull. Ent. Soc. Egypt. 75, 156-159.

Anonymous, 2004. Ministry of Agric. Sugar crops council Data.

Besheit, S.Y., Abaziad, A.A., EL-Gpmaa, A.M., Abo EL-Hamd, A.S., 2002. The influence of the infestation by the soft scale insect, Pulvanaria tenuivalvata (Newstead), Coccidae: Homoptera on sugarcane stalk weight, juice quality and sugar yield in Upper Egypt. Assut J. Agric. Sci. 33 (4), 17-28.

Fisher, A.G.A., 1950. Statistical Tables for Biological and Medical Research, $6^{\text {th }}$ ed. Oliver \& Boyd, London.

Maareg, M.F., Hassanein, M.A., Abu Dooh, A.M., 1992. Preliminary survey of the scale insects attacking sugarcane in Egypt. Comm. Sci. Dev. Res. 495, 223230.

Rao, V.P., Sankaran, T., 1969. The Scale Insect if Sugarcane: Pests of Sugarcane: Elsevier Publishing Co., London, pp. 325-342.

Shalaby, M.S.I., 2002. Ecological and Biological Studies on the Sugarcane Scale Pulvinaria tenuivalvata (Newstead) infesting sugarcane in Giza Governorate. Ph.D. Thesis, Al-Azhar Univ., Cairo, p. 209.

Valand, V.M., Patel, J.I., Mehta, D.M., 1989. Biology of brown scale (Saissetia coffeae) on pointed groud (Trichosanthes dloica). Ind. J. Agric. Sci. 59 (9), 610-611.

Table 1. Mean number of $P$. tenuivalvatain relation to weather factors Maximum, minimum temperature and relative humidity in sugarcane fields in Awadalah District, Aswan Governorate during 2015.

\begin{tabular}{|c|c|c|c|c|c|c|}
\hline \multirow{2}{*}{\multicolumn{2}{|c|}{ Sampling date }} & \multirow{3}{*}{$\begin{array}{c}\text { Insects. } \\
31\end{array}$} & \multicolumn{4}{|c|}{ Weather factors } \\
\hline & & & \multirow{2}{*}{$\frac{{ }^{1} \text { Max.temp },{ }^{\circ} \mathrm{C}}{33.82}$} & \multirow{2}{*}{$\frac{{ }^{2} \mathrm{Min} \text { temp },{ }^{\circ} \mathrm{C}}{15.95}$} & \multirow{2}{*}{$\frac{\text { Me. Temp., }{ }^{\circ} \mathrm{C}}{24.88}$} & \multirow{2}{*}{$\frac{3 \mathrm{RH}, \%}{64.93}$} \\
\hline May & $15 / 5 / 2015$ & & & & & \\
\hline & 30 & 42 & 36.41 & 17.07 & 26.74 & 65.52 \\
\hline \multirow{2}{*}{ June } & 15 & 49 & 40.02 & 21.4 & 30.71 & 63.82 \\
\hline & 30 & 63 & 39.02 & 20.6 & 29.81 & 62.56 \\
\hline \multirow{2}{*}{ July } & 15 & 97 & 41.06 & 23.22 & 32.14 & 62.3 \\
\hline & 30 & 112 & 42.91 & 24.23 & 33.57 & 59.14 \\
\hline \multirow{2}{*}{ August } & 15 & 135 & 41.32 & 26.25 & 33.78 & 62.95 \\
\hline & 30 & 187 & 42 & 25.27 & 33.63 & 62.45 \\
\hline \multirow{2}{*}{ Septe. } & 15 & 215 & 42.56 & 26 & 34.28 & 59.83 \\
\hline & 30 & 230 & 41.67 & 25.9 & 33.78 & 61.31 \\
\hline \multirow{2}{*}{ Octob. } & 15 & 198 & 41.62 & 24.4 & 33.01 & 62 \\
\hline & 30 & 161 & 39.19 & 22.77 & 30.98 & 64.55 \\
\hline \multirow{2}{*}{ Nov. } & 15 & 138 & 31.46 & 16.66 & 24.06 & 72.98 \\
\hline & 30 & 112 & 28.68 & 14.7 & 21.69 & 72.17 \\
\hline \multirow{2}{*}{ Dec. } & 15 & 72 & 23.56 & 8.44 & 16 & 74.7 \\
\hline & 30 & 45 & 20.58 & 7.5 & 14.04 & 74.4 \\
\hline \multirow[t]{3}{*}{ Jan } & $15 / 1 / 2016$ & 22 & 23.1 & 6.77 & 14.93 & 75.33 \\
\hline & Total & 1909 & 608.98 & 327.13 & 468.05 & 1120.94 \\
\hline & Me. & 112.29 & 35.82 & 19.24 & 27.53 & 65.93 \\
\hline
\end{tabular}

Averages for the week before the mean number of infestation

Averages for the week before the mean number of infestation

Averages for the two week before the mean number of infestation

Table 2. Mean number of $P$. tenuivalvatain relation to weather factors Maximum, minimum temperature and relative humidity in sugarcane fields in Awadalah District, Aswan Governorate during 2016.

\begin{tabular}{|c|c|c|c|c|c|c|}
\hline \multicolumn{2}{|c|}{ Sampling date } & \multirow{2}{*}{ Insect. } & \multicolumn{4}{|c|}{ Weather factors } \\
\hline & & & Max. temp, ${ }^{\circ} \mathrm{C}$ & Min temp., ${ }^{\circ} \mathrm{C}$ & Me. Temp., ${ }^{\circ} \mathrm{C}$ & $\mathrm{RH}, \%$ \\
\hline \multirow{2}{*}{ May } & $15 / 5 / 2016$ & 21 & 37.68 & 19.88 & 28.78 & 59.91 \\
\hline & 30 & 34 & 41.09 & 22.85 & 31.97 & 57.18 \\
\hline \multirow{2}{*}{ June } & 15 & 43 & 41.01 & 23.07 & 32.04 & 57.49 \\
\hline & 30 & 56 & 40.08 & 21.81 & 30.94 & 62.89 \\
\hline \multirow{2}{*}{ July } & 15 & 67 & 40.64 & 22.85 & 31.74 & 63.01 \\
\hline & 30 & 82 & 43.47 & 25.71 & 34.59 & 62.51 \\
\hline \multirow{2}{*}{ August } & 15 & 103 & 45.12 & 29.89 & 37.50 & 58.23 \\
\hline & 30 & 128 & 43.99 & 27.99 & 35.99 & 59.57 \\
\hline \multirow{2}{*}{ Sept.. } & 15 & 148 & 42.26 & 25.32 & 33.79 & 63.08 \\
\hline & 30 & 161 & 41.83 & 26.48 & 34.15 & 61.61 \\
\hline \multirow{2}{*}{ Oct.. } & 15 & 178 & 38.83 & 23.51 & 31.17 & 65.84 \\
\hline & 30 & 153 & 35.97 & 22.65 & 29.31 & 71.93 \\
\hline \multirow{2}{*}{ Nov. } & 15 & 121 & 28.56 & 13.74 & 21.15 & 76.48 \\
\hline & 30 & 78 & 28.25 & 14.16 & 21.20 & 78.55 \\
\hline \multirow{2}{*}{ Dec. } & 15 & 44 & 22.22 & 7.75 & 14.98 & 79.95 \\
\hline & 30 & 20 & 21.69 & 6.17 & 13.93 & 81.03 \\
\hline Jan. & $151 / 2017$ & 8 & 22.1 & 7.1 & 14.6 & 79.9 \\
\hline \multicolumn{2}{|r|}{ Total } & 1445 & 614.79 & 340.93 & 477.86 & 1139.16 \\
\hline \multicolumn{2}{|c|}{ Me. } & 85 & 36.16 & 20.05 & 28.10 & 67.00 \\
\hline
\end{tabular}

1: Averages for the week before the mean number of infestation.

2: Averages for the week before the mean number of infestation.

3: Averages for the two week before the mean number of infestation. 
Table 3. Simple correlation ( $\mathrm{r}$ ), and partial regression values of environmental parameters on the population density of soft scale insect $P$. tenuivalvata season (2015-2016).

\begin{tabular}{clcccc}
\hline Year & Environmental factors & $\mathrm{R}$ & $\mathrm{B}$ & $\mathrm{f}$ & $\mathrm{E}$.V. \% \\
\hline \multirow{2}{*}{2015} & Max. temp., ${ }^{\circ} \mathrm{C}$ & -0.6281 & -2.95 & & \\
& Min. temp., ${ }^{\circ} \mathrm{C}$ & -0.5931 & 3.22 & 8.78 & 64.35 \\
& R.H. , \% & 0.8612 & 3.92 & & \\
\cline { 2 - 6 } 2016 & Max. temp., ${ }^{\circ} \mathrm{C}$ & -0.6109 & -3.68 & & \\
& Min. temp., ${ }^{\circ} \mathrm{C}$ & -0.5428 & 2.11 & 11.21 & 71.2 \\
& R.H. , \% & 0.612 & 3.21 & & \\
\hline
\end{tabular}

r: Simple correlation co-efficient; b: regression coefficient; $p$ : Probability level; E.V: Explained Variance. 


\title{
Pulvinaria tenuivalvata (Newstead) ارتباط العوامل البيئة بالثغير في كثافة تعداد حشرة قصب السكر القشرية الرخوة
}

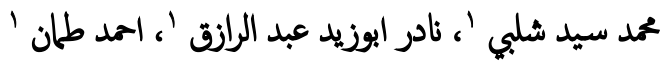

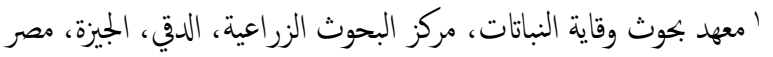

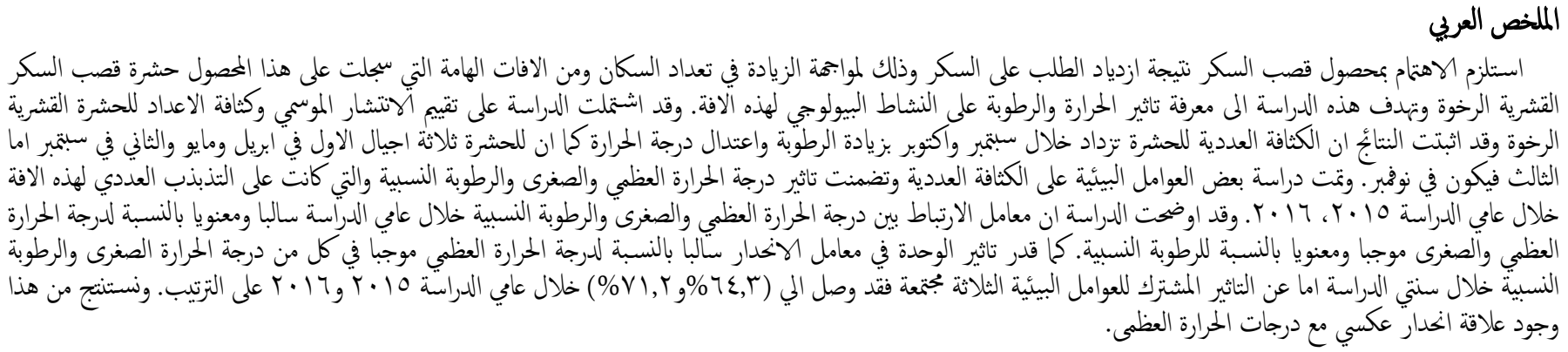

